ホルマリンガス殺菌・無毒化法の残留毒性の生物学的評価 平田統- ${ }^{1)} \quad$ 吉田 敬 ${ }^{2)}$ 安田 準 ${ }^{3)}$

1) 岩手大学農学部附属寒冷フィールドサイエンス教育研究センター御明神牧場、 2) (株アアスカメディカル、3) 岩手大学農学部附属動物病院

\title{
Biological Evaluation of Residual Toxicity of Formaldehyde Gas Sterilization and Neutralization Method
}

\author{
T-I. Hirata ${ }^{1)}$, T. Yoshida ${ }^{2)}$, J. Yasuda ${ }^{3)}$
}

1) Omyojin Animal Farm, Field Science Cener, Faculty of Agriculture, Iwate University,

2) Asuka Medical co.

3) Veterinary Teaching Hospital, Faculty of Agriculture, Iwate University

要 約 ホルマリンガス（FG）殺菌・無害化装置「Holl Steri」（アスカメディカル）の残留毒性を、 従来法のエチレンオキサイドガス（EOG）殺菌法のそれと比較して、生物学的に評価した。0.25 $\mathrm{ml}$ トローに 6 時間保存した精子生存率において、FG区は無殺菌の対照区に比べ 6 時間目で有意 $(\mathrm{p}<0.01)$ に生存率が減少した。しかし、FG区はEOG区に比べて有意（2 時間目：p<0.01、4 時間目: $\mathrm{p}<0.05)$ に生存率が高かった。3日間の胚盤胞期牛胚培養において、FG区はガンマ線殺菌の対照区に比べ 2 日 目で有意 $(\mathrm{p}<0.01)$ に生存率が減少し、2.5日目にはすべての胚が死滅した。しかし、EOG区に対して は、培養後 $1 、 2$ 日目に、有意 $(\mathrm{p}<0.01)$ に生存率が高かった。10日間前後の牛卵子の体外成熟・受 精・培養系にお゙いて、FG区およびガンマ線殺菌の対照区の 5 細胞期以上への分割率と胚盤胞への発生

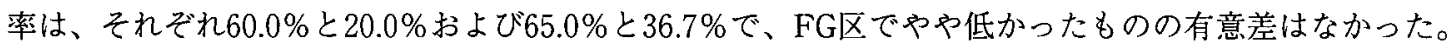
一方、EOG区での胚発生はなかった。以上の結果から、FG殺菌・無毒化装置による殺菌では、無殺菌 やガンマ線滅菌に比べ細胞毒性の残存がみられるが、従来広く用いられてきたEOG殺菌に比べ残留毒 性は極めて少ないことが示された。

-一-・ーワード：ホルマリンガス、殺菌、無毒化、残留毒性、生物学的評価

家畜臨床誌 $27(2): 51-55,2004$

ABSTRACT The residual toxicity of formaldehyde gas (FG) sterilization and neutralization equipment, "Holl Steri" (Asuka Medical), was evaluated biologically and compared with the conventional ethylene oxide gas (EOG) disinfectant process. The percentage of FG group motile spermatozoa, preserved in $0.25 \mathrm{ml}$ straws for 6 hours, compared with the non-sterilized control group, decreased significantly $(\mathrm{p}<0.01)$ in the 6th hour. However, FG group had significantly higher survival rate than EOG group ( 2 nd hour $: p<0.01 ; 4$ th hour $p<0.05$ ). In bovine embryo culture 
for three days, the embryo survival rate decreased significantly $(\mathrm{p}<0.01)$ in $\mathrm{FG}$ group compared with control group of gamma ray sterilization on the 2 nd day, and, at 2.5 days, all embryos were nonviable. However, compared with EOG group, embryo survival rate in FG group was significantly $(p<0.01)$ higher on the 1 st and 2 nd days. In the in vitro maturation, fertilization and culture system of bovine oocytes for about ten days, the division rates into five or more-celled embryos and the blastocyst generation rates in FG group and control group of gamma ray sterilization were 60.0 , and $20.0 \%$, and 65.0 and $36.7 \%$, respectively. Although rates were a little lower in FG group, there was no significant difference between groups. On the other hand, there was no embryonic growth in EOG group. These results suggest there was slight residual cell toxicity with FG sterilization and neutralization equipment compared with non-sterilizing or gamma ray sterilization, however there was very little residual toxicity compared with the widely employed conventional EOG sterilization.

- Key Words : Formaldehyde gas, sterilization, neutralization, residual toxicity, biological evaluation

Jpn. J. Vet. Cinics 27(2):51-55, 2004

\section{緒 言}

家畜生産、とくに牛の繁殖に扔いて、近年、多排卵誘 起・回収、経腟生体内卵子吸引一体外受精・培養、胚移 植などの新規諸技術が盛んに利用されるようになってい る。これらの技術が安全に利用されるためには器具器材 の殺菌操作が不可欠である [7] が、ポリエチレンやポ リプロピレン、塩化ビニル製の器材など、高温に耐えら れないものも多い。これら耐熱性の低い器材の殺菌には、 一般にエチレンオキサイドガス（EOG）が用いられて きた。EOGは、操作が容易で殺菌効果が優れているが、 特定化学物質等第 2 類物質に指定されており、その殺菌 操作に当たっては、特定化学物質等作業主任の有資格者 が必要なほか、排気設備の設置や、従事者の健康診断、 作業環境測定が義務付けれらるなど、様々な制限がある [9]。また、残留毒性にも問題がある $[2 ， 7]$ 。さら に殺菌・浄化に要する時間が比較的長く、短期間に繰り 返し使用する器材の殺菌に不向きな面もある [4]。一 方、ホルマリンの低温蒸気殺菌法もまた熱不安定な器材 の低温殺菌法として有用性や安全性が証明されてきた [4，5］が、畜産分野での利用は限られてきた。ホル マリンは特定化学物質等第 3 類物質に指定されているが、 EOGに比べて取り扱いが容易で規制が少ない。また、 殺菌に要する時間がEOG殺菌に比べ短いことから、器 具の予備を必要最小限に抑えることができ、コス卜削減 にもつながるなど、畜産現場で活用し得るものと期待で きる。ホルマリンガス殺菌・無害化装置「Holl Steri」 (アスカメディカル) は、ホルマリンガス（FG）を用い る殺菌装置で、ガスの净化・中和が自動化され、より安
全で簡便に滅菌操作が実施できる。本装置を用いたFG 殺菌法の殺菌効果について、武藤ら [5] は、動物で頻 繁にみられる感染の原因菌に対し殺菌効果があり、生体 への影響は少ないと報告している。本試験ではFG殺菌・ 無毒化法を畜産の現場で安全に用いるための基礎的知見 を得るために、EOG殺菌法と比較しながら、牛精子や 胚盤胞期牛胚の保存、牛卵子の体外培養系を用いて、短 期間・中期間 - 長期間処理の残留毒性を生物学的手法で 検討した。

\section{材料と方法}

実験 1 : 短期間処理の残留毒性を 6 時間前後の凍結融 解精液中の精子性状で評価した。塩化ビニル製の $0.25 \mathrm{ml}$ ストロー（富士平工業）を殺菌せず市販の状態で（対照 区)、あるいはFG殺菌（FG区）、EOG殺菌（EOG区）し て用いた。すなわち、FG区ではストローをハイブリッ ドメッキンバック（HM-1302、ホギメディカル）に入れ、 「Holl Steri 20」(アスカメディカル) のTBモード（加 温 $50^{\circ} \mathrm{C}$ 、殺菌240分、净化210分、全工程 7 時間30分) で 殺菌浄化後、空気中で約65時間放置して用いた。EOG 区ではFG区と同様にメッキンバックに入れたストロー をEOG滅菌器「Elpack」(イキ)を用いて、EOGを充填 したラミステラ (西本産業) 中に 6 日間静置し、強制換 気でガス置換後、空気中で約65時間放置して用いた。

凍結黑毛和種精液（Pクロ404、家畜改良事業団）は、 $38^{\circ} \mathrm{C}$ の温湯中で融解後、媒精液 (IVF100、機能性ペプ チド研究所）を用いて $3 \times 10^{6} \mathrm{sperm} / \mathrm{ml}$ に濃度調整して 各区のストローに充填し、ヒートシールで密閉した。 
$38.5^{\circ} \mathrm{C}$ 炭酸ガス培養器 (4020、朝日ライフサイエンス) 内に静置して $0 、 2 、 4 、 6$ 時間後に精子の生存率と運 動性を観察した。精子生存率は、hoechst 33342 (Sigma) とPropidium Iodide（Sigma）を用いた蛍光 2 重染色法 により確認した。精子運動性は、運動性を有している精 子の割合と運動の強度を観察し、指数化した [8]。

実験 $2:$ 中期間処理の残留毒性を 3 日間前後の牛胚培 盖で評価した。ポリスチレン製で表面を1型コラーゲン で被覆している培養シャーレ（リプロC 1、機能性ペプ チド研究所）を市販の状態で（ガンマ線殺菌、対照区）、 あるいはFG殺菌、EOG殺菌して供試した。すなわち、 FG区ではシャーレをハイブリッドメッキンバックに入 れ、TBモードで殺菌無毒化後、空気中で約42時間放置 して用いた。EOG区ではEOGを充填した滅菌バック中 に 4 日間静置し、強制換気でガス置換後、空気中で約 24 時間放置して用いた。牛胚は、機能性ペプチド研究所の 方法 [11］を用い、と畜場卵巣由来の未成熟卵子を黒毛 和種精液（Pク口404、家畜改良事業団）で体外成熟 . 受精・培盖して体外で生産 (IVP: in vitro production) した。肧日齢 7 から 8 日の胚盤胞期肧で品質ランクとし てgood以上を供試した。ガラス化凍結・融解後、1 ら 2 時間の回復培養を行って、各試験区に胚品質のばら つきが最小になるように各区シャーレに分配し、 $38.5^{\circ} \mathrm{C}$ のマルチガス培養器（APM-30D、アステック）内に静 置して、 $5 \% \mathrm{CO}_{2} 、 5 \% \mathrm{O}_{2} 、 90 \%$ 空気の条件で、0、 $1 、 2 、 2.5 、 3$ 日後に牛胚の生存率と睑化率を観察し た。

実験 3 : 長期間処理の残留毒性を10日間前後の牛卵子 体外受精・培盖法で評価した。FG区、EOG区ともに、 実験 2 で準備した培養シャーレに培養液を満たしてマル チガス培養器中で 9 日間放置した後、培養液を全量交換 してして実験に用いた。実験 2 と同様にIVPを行い、体 外受精日を 0 日として 2 日目の 5 細胞期以上への分割率、 および 7,一10日目の胚盤胞への発生率を観察した。

\section{成 績}

実験 $1 ：$ 精子生存率において、滅菌処理していない対 照区が試験期間を通し最も高い值を示した。FG区では 対照区に比べ、 2 時間目、4 時間目で有意差を認めなかっ たものの、6 時間目で有意 $(\mathrm{p}<0.01)$ に生存率が減少 した。また、EOG区では対照区に比べ、培養後 2 時間 目以降有意 $(\mathrm{p}<0.01)$ に生存率が減少した。一方、FG 区とEOG区を比較すると、FG区では 2 時間目 $(\mathrm{p}<0.01)$ 抢よび 4 時間目（ $\mathrm{p}<0.05 ） に$ 精子生存率が有意に高かっ
た（図 1)。精子運動性については、各区で大きな違い はみられなかったが、FG区で他の 2 区よりも運動性に 及ぼす障害の程度がやや大きかった（図2）。

実験 $2:$ 牛胚生存率において、ガンマ線滅菌した対照 区が試験期間を通し最も高い值を示した。FG区では対 照区に比べ、1日目で有意差を認めなかったものの、2 日目で有意 $(\mathrm{p}<0.01)$ に生存率が減少し、2.5日目には 寸べての肧が死滅した。また、EOG区では培養後 1 日 目にすべての胚が死滅した。一方、FG区とEOG区を比 較すると、FG区では培養後 1 と 2 日目に、有意 $(\mathrm{p}<0.01)$ に生存率が高かった（図 3$)$ 。牛肧睬化率に おいて、対照区に対LFG区は 2 日目以降有意 $(p<0.01)$ に低率であった（図 4)。

実験 3 : 体外受精日を 0 日として 2 日目の 5 細胞期以 上への分割率、および $7-10$ 目の肧盤胞への発生率を指 標としたところ、ガンマ線滅菌した対照区が、分割率 $65.0 \%$ 、胚盤胞率 $36.7 \%$ で最も高い值を示した。これに

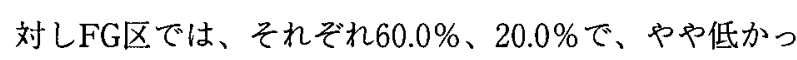
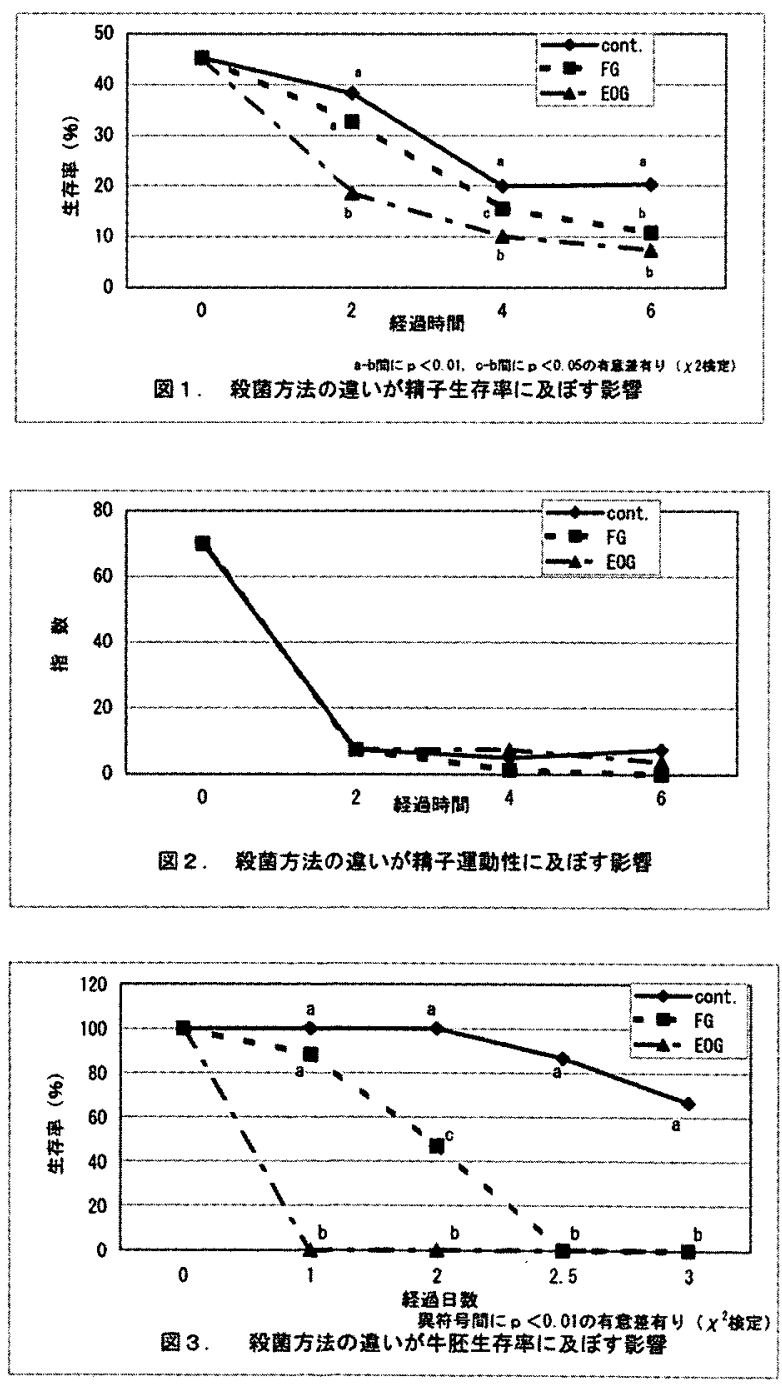

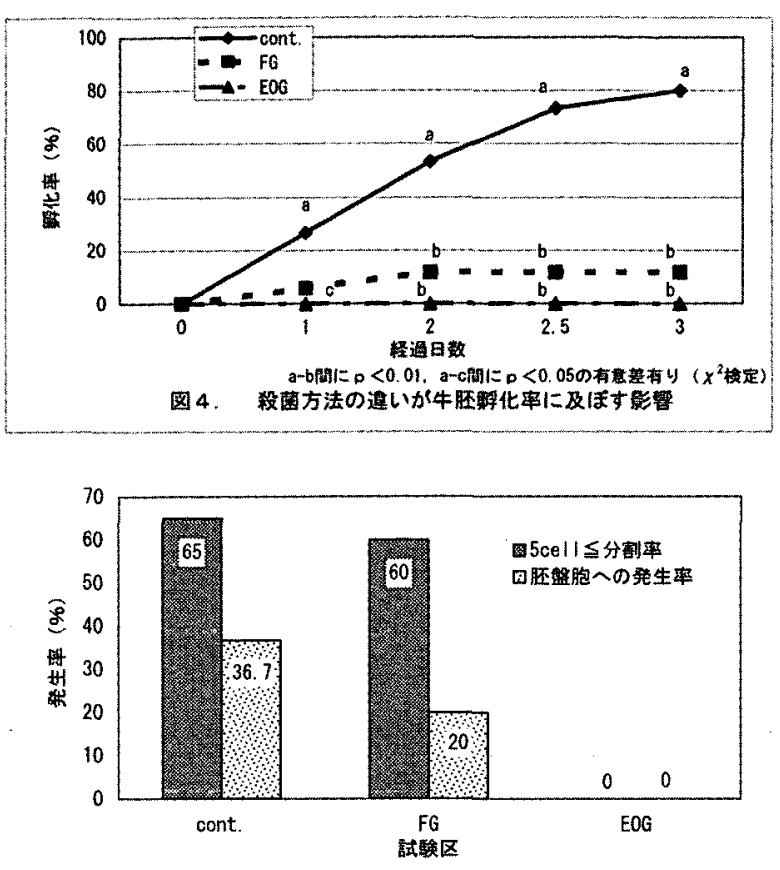

图 5. 殺菌方法の違いが牛胚体外受精・培養に及ほす影知

たものの有意差はなかった。一方、EOG区では、胚発 生を認めなかった（図 5 )。

\section{考 察}

胚の体外培養や移植など家畜生産における近年の新規 諸技術は、家畜の生産と育種効率を大幅に向上させる技 術として応用されてきている。しかしながら、人工授精 に比べ体外で生産された牛胚由来産子の妊娠期間は延長 し、生時体重が増え、生後死亡率や難産発生率が増える [10] などの課題もあり、さらなる技術の改善が求めら れている。これら新規諸技術に使用される器材は、生体 を感染症から守り、胚培養を成功裏に実施するために殺 菌されなければならない。一般に耐熱性の低い機材の殺 菌にはEOGが用いられているが、EOGには強い細胞毒 性があり [2，7]、胚の生存性や活力に悪影響を及ぼ し、結果として胚移植後の受胎率や産子の正常性を傷害 する可能性がある。そこで本試験では、一般的に用いら れているEOG殺菌とホルマリンガス殺菌・無害化装置 によるFG殺菌の残留毒性を生物学的に比較検討した。

その結果、凍結融解精液を指標にした短期間残留毒性 については、FG区はEOG区に対して有意に生存率が高 かったこと、牛胚盤胞を指標にした中期間残留毒性につ いては、培養後 $1 、 2$ 日目の胚生存率が有意に高かった こと、牛未成熟卵子のIVPを指標とした長期間残留毒性 については、EOG区では全く胚が発生せず著しい細胞 毒性を示したのに対し、FG区は対照区の発生率と有意 差がなかったことなどから、FG殺菌はEOG殺菌に比べ
細胞毒性の残存はごくわずかであり、牛生殖細胞などを 取り扱う場で利用できることが実証された。また、5細 胞期以上への分割率および胚盤胞への発生率ともに、 FG殺菌区の成績に影響を及ばさなかったことから、減 菌した培養血を 9 日間 $38.5^{\circ} \mathrm{C}$ のインキュベータで保持し、 かつ、使用直前に培養液を交換して牛胚の体外培盖を開 始する実験系では残留毒性は少ないものと考えられた。 このことからシャーレへのFG吸着は強固なものではな く、培養液中に溶け出す程度のものであったと予想され た。このようなFGとEOGにおける残留毒性の相違は、 ガスそのものの毒性の相違やストロー、シャーレへの吸 着の程度に関連するほか、FG殺菌装置自体に自動の無 毒化工程を含んでいる優位性によると考えられた。装置 自体に無毒化工程を含むことは効率のうえからも有利で ある。Kanemitsuら [4] は、EOG殺菌には少なくとも 24時間必要であるのに対し、低温ホルマリンガス殺菌で は 3 から 7 時間を要するに過ぎず、内視鏡などの日々使 用される医療用器具の殺菌に有用であると述べている。 一方、Nakataら [6] は、硬質容器中にポリ塩化ビニ ルを入れEOG滅菌した結果、毒性を除くには17時間以 上の通気が必要であったと述べている。さらにHolyoak ら [1] は、牛の体外培養系に扔いて、EOG殺菌後の 培養シャーレを12日間通気しても毒性を除くことはでき なかったことを示している。本試験で用いたFG殺菌、 無害化装置ではTBモードにおける浄化を含めた全工程 で 7 時間30分、通常の器具殺菌モードで全工程 2 時間30 分であったのに対し、EOG殺菌において毒性を残さな いようなガスの㕬散を待つためには 42 時間放置でも不十 分 [実験 3 ] であったことからも、FG滅菌はEOG殺菌 に比べ頻回使用される器材を短時間で効率的に処理でき、 かつ予借の器具を保つ必要性が隇ることから低コストに 結びつく殺菌方法であるといえる。EOG殺菌した培養 シャーレを用いて牛胚のIVPを行っても卵割を含め胚発 生を全く認めず、Holyoakら［1］の報告と同様であっ た。彼らはEOGは扔そらく卵母細胞に対するより精子 に対する毒性が強く、その結果体外受精に失敗すること が卵割しない原因だろうと考察している。

今後畜産新技術分野でFG滅菌法を活用するうえでさ らに検討すべき事項も示された。精子運動性において、 有意差はなかったものの観察上はFG区の運動性が最も 低かった。このような現象はFG殺菌に普遍的なことな のか、それとも特殊な要因によるものか検討する余地が ある。今回用いた精液の活性が比較的低く、保存後 2 時 間でいずれの区も急激に運動性が減少したことから、相 
違がみえにくく観察結果に影響した可能性があるので、 異なる種雄牛の凍結融解精子を供試して観察することが 必要かもしれない。また、ガンマ線殺菌などの対照区に 比べればFG殺菌にも残留毒性があることが示されたの で、より安全にFG殺菌を活用するためにはさらに残留 毒性を減らす工夫が必要である。今回の試験では、TB モード（加温50 $0^{\circ} \mathrm{C} 、$ 殺菌240分、净化210分、全工程 7 時 間30分) で殺菌净化を行ったが、通常の器具殺菌モード (加温 $50^{\circ} \mathrm{C}$ 、殺菌60分、净化 90 分、全工程 2 時間 30 分) で殺菌净化すればさらに残留毒性は少なくなると期待さ れる。また、通気時間や通気方法などFGの浄化行程を 検討することで、十分な殺菌と安全がともに得られる殺 菌法となり得る。

本試験では毒性の発現時期に違いが見られた。すなわ ち実験 1 の精子生存率では、保存後 4 時間に対照区との 間に有意差が見られたのに対し、実験 2 の胚の中期間培 盖では培養後 2 日に有意差が見られた。先に述べたよう に、毒性の残留には殺菌処置後の通気時間や通気方法が 影響する。加えて、FGの残留の程度は、器材の形状や 材質によって異なり、天然ゴムが残留が最も高く、次い で塩化ビニル、ポリウレタン、次いで明らかな差をもっ てポリプロピレン、ポリエチレンの順であったことが報 告されている [3] こと、用いたストローは外径が $2 \mathrm{~mm}$ 前後の筒状で塩化ビニル製、シャーレは平状でコラーゲ ンで被覆されたポリスチレン製など形状と材質が異なる ことなどから、毒性が示される時期の違いはストローと シャーレの形状や原材料の違いに起因するものと考えら れた。残留毒性と器材の形状、素材との関連についてさ らに検討する必要がある。

FG殺菌・無害化装置「Holl Steri」が動物で頻繁にみ られる感染症の原因菌に対し十分な殺菌効果があること は既に報告されている [5]。本試験の結果から、FG殺 菌が、多排卵誘起・回収、経胵生体内卵子吸引一体外受 精・培養、胚移植などの畜産関連新規諸技術で用いる生 殖細胞を短期間扱う器材の殺菌において、従来のEOG 殺菌よりも安全で作業時間が短時間で済み、法規制上の 取り扱いも容易な [9]、音産現場で活用できる装置で あることが示された。

\section{引用文献}

1. Holyoak, GR., Wang, S., Liu Y. and Bunch, TD. (1996). Toxic effects of ethylene oxide residues on bovine embryos in vitro. Toxicology. 108:33-38.

2. The Japan Society for Occupational Health (2000).
Recommendation of occupational exposure limits. J Occup Health. $42: 213-228$.

3. 加見谷将人, 福島伸明, 田中清司, 小野民子, 磯崎 博司（2003）。ホルムアルデヒドガスの殺菌効果なら びに残留の検討. 医器学 $73: 657-658$.

4. Kanemitsu, K., Kunishima, H., Imasaka, T., Ishikawa, S., Harigae, H., Yamato, S., Hirayama, Y. and Kaku, M. (2003). Evalution of a low-temperature steam and formaldehyde sterilizer. J. Hosp Infect. $55: 47-52$.

5. 武藤 恵, 蘇 延根, 杉井俊二, 青木美香, 片本 宏, 嶋田照雅, 伊藤喜久治, 遠矢幸信, 高野 剬, 大 橋文人（2003）。動物病院でのホルマリンガス殺菌 の有効性を評価.日本獣医公衆衛生学会（近畿）講演 要旨集 pp88.

6. Nakata, S., Umeshita, K., Ueyama, H., Takashina, M., Noguchi, S., Murata, A. and Ochi, T. (2000). Aeration time following ethylen oxide sterilization for reusable rigid sterlization containers: concentration of gaseous ethylen oxide in containers. Biomed Instrum Technal, $34: 121-124$.

7 . 日本家畜人工授精師協会（1996）。家畜人工授精講 習会テキスト(家畜受精卵移植編)。pp203-205，日本 家畜人工授精師協会, 東京.

8. 丹羽太左衛門, 門司恭典, 橋爪力, 塩谷康生 （1998）。家畜の人工授精と受精卵移植。pp61-65，創 文, 東京.

9 . 特定化学物質等障害子防規則. 昭和 47 年 09 月 30 日制 定. 労㗢省令第39号.

10. van Wagtendonk-de Leeuw, AM., Aerts, BJ. and den Daas, JH. (1998). Abnormal offspring following in vitro production of bovine preimplantation embryos : a field study. Theriogenology. $49: 883-894$.

11. Yamashita, S., Satoh, T. and Hoshi, H. (1996). Bovine blastocyst formation from IVM/TVF produced zygotes in serum and serum free medium. Theriogenology $45: 197$. 